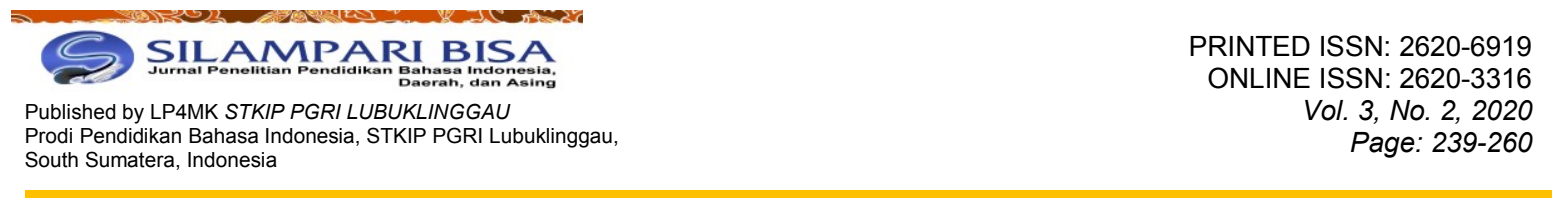

\title{
MODEL AKSI INSIDEN BERBASIS CLASSROOM SEBAGAI ALTERNATIF DALAM MENINGKATKAN KEMAMPUAN MENULIS TEKS EKSPLANASI SISWA PADA MASA PANDEMI COVID-19
}

\author{
Nora Vitaria \\ SMAN 8 Kota Bengkulu \\ Provinsi Bengkulu, Indonesia \\ Email: vitarianora1@gmail.com
}

\begin{abstract}
Abstrak
Penelitian ini bertujuan mendeskripsikan penerapan model aksi insiden berbasis classroom dalam meningkatkan kemampuan menulis teks eksplanasi siswa pada masa pandemi Covid-19. Metode penelitian menggunakan metode Penelitian Tindakan Kelas dengan model Kemmis dan Mc Taggart. Penelitian tindakan kelas ini dilaksanakan dalam 2 siklus. Setiap siklus ada 2 pertemuan. Subjek penelitian yaitu siswa kelas XI IPA 1 SMAN 8 Kota Bengkulu, tahun ajaran 2020/2021. Instrumen yang digunakan berupa tes dan nontes. Teknik pengumpulan data melalui 1). Dokumentasi berupa aplikasi Geogle Classroom, Geogle From, dan Geogle Dokumen, 2) tes berupa tes pilihan ganda dan esai, serta 3) angket, untuk mengetahui respons siswa terhadap penerapan model aksi insiden berbasis classroom. Langkah analisis melalui reduksi data, penyajian data, dan penarikan kesimpulan. Hasil penelitian menunjukkan bahwa penerapan model aksi insiden berbasis classroom mampu meningkatkan kemampuan menulis teks eksplanasi pada masa pandemi Covid-19. Hal ini ditunjukkan dengan sebelum menerapkan model aksi insiden siswa memperoleh hasil belajar dengan nilai rata-rata sebesar 73,44 dengan kategori Baik dan meningkat sesudah diterapkannya model aksi insiden dengan nilai rata-rata sebesar 83,16 dengan kategori Sangat Baik. Hasil siklus 1 ke 2 mengalami kenaikan $1,16 \%$. Kemudian, hasil angket diperoleh $63,75 \%$ siswa setuju model aksi insiden berbasis classroom diterapkan masa pandemi Covid-19, diperoleh dengan kategori Baik. Model aksi insiden berbasis classroom memiliki kelebihan mampu meningkatkan kreativitas siswa ketika proses kegiatan menulis teks eksplanasi karena setiap individu dalam kelompok menyumbangkan idenya dalam bentuk tulisan eksplanasi.
\end{abstract}

Kata kunci: model aksi insiden, classroom, pandemi Covid-19, menulis teks eksplanasi

\section{CLASSROOM-BASED INCIDENT ACTION MODELS AS AN ALTERNATIVE IN IMPROVING STUDENTS' EXPLANATORY TEXT WRITING SKILLS DURING THE COVID-19 PANDEMIC}

\begin{abstract}
This study aims to describe the application of the classroom-based incident action model in improving students' explanatory text writing skills during the Covid-19 pandemic. The research method used was Classroom Action Research with the model of Kemmis and Mc Taggart. This classroom action research was conducted in 2 cycles. Each cycle has 2 meetings. The research
\end{abstract}


subjects were students of class XI IPA 1 SMAN 8 Bengkulu City, school year 2020/2021. The instruments used were tests and non-tests. Data collection techniques through 1). Documentation in the form of Geogle Classroom, Geogle From, and Geogle Docs applications, 2 ) tests in the form of multiple choice tests and essays, and 3) questionnaires, to determine student responses to the application of classroom-based incident action models. The analysis step is through data reduction, data presentation, and conclusion drawing. The results showed that the application of the classroom-based incident action model was able to improve the ability to write explanatory text during the Covid-19 pandemic. This is indicated by before applying the incident action model students obtained learning outcomes with an average score of 73.44 in the Good category and increased after the implementation of the incident action model with an average score of 83.16 in the Very Good category. The result of cycle 1 to 2 increased by $1.16 \%$. Then, the results of the questionnaire obtained were $63.75 \%$ of students agreed that the classroom-based incident action model was applied during the Covid-19 pandemic, obtained in the Good category. The classroom-based incident action model has the advantage of being able to increase student creativity when writing explanatory text activities because each individual in the group contributes ideas in the form of explanatory writing.

Keywords: incident action models, classrooms, Covid-19 pandemic, writing explanatory text

\section{A. Pendahuluan}

Mewabahnya Covid-19 merupakan masalah dunia sehingga perubahan tatanan terjadi secara global dengan kurun waktu yang tidak bisa ditentukan. Merebaknya wabah Covid-19 belum ada tanda-tanda akan berakhir. Saat ini pasien Covid-19 masih tinggi. Sementara itu, pendidikan harus berlangsung, tidak boleh terhenti. Oleh sebab itu, pembelajaran daring adalah salah satu alternatif pembelajaran yang cocok dengan kondisi pademi Covid-19 yang mengganggu proses pembelajaran secara konvensional. Hal ini senada dengan pendapat Sadikin \& Hamidah (2020:109-110), pembelajaran daring merupakan pembelajaran yang menggunakan jaringan internet dengan aksesibilitas, konektivitas, fleksibilitas, dan kemampuan untuk memunculkan berbagai jenis interaksi pembelajaran. Salah satu media yang utama adalah handphone.

Seiring perkembangan zaman, tugas guru untuk meningkatkan kualitas siswa tidak berjalan mulus. Guru mendapat tantangan berat. Tantangan menghadapi abad ke- 21, masa era digital, guru harus profesional memanfaatkan teknologi digital, terutama pembelajaran masa pandemi Covid- 19 ini. Guru dituntut mampu memandu siswa dalam pembelajaran jarak jauh (PJJ). Sesuai dengan Keputusan Kepala Badan Penelitian dan Pengembangan dan Perbukuan Nomor 018/H/KR/2020 tentang Silabus PJJ khusus Pandemi Covid-19 dan surat 
edaran Sekjen Kementerian P \& K No. 15 tahun 2020 tentang Pedoman Penyelenggaraan Belajar dari Rumah dalam Masa Darurat Penyebaran Covid-19.

Pembelajaran daring merupakan kegiatan pembelajaran yang memanfaatkan jaringan (internet, LAN, WAN) sebagai metode penyampaian, interaksi, dan fasilitasi serta didukung oleh berbagai bentuk layanan belajar lainnya (Mustofa dkk., 2019:154). Media pembelajaran daring yang kerap digunakan adalah aplikasi WhatsApp.

Penerapan PJJ ini, timbul permasalahan baru, banyak mengalami hambatan. Hal ini disebabkan kondisi dan situasi akibat Covid-19 telah mengakibatkan perubahan tatanan kesehatan, ekonomi, sosial, budaya dan pendidikan. Terutama segi ekonomi, masyarakat banyak kehilangan pekerjaan. Kehidupan ekonomi semakin terpuruk, sehingga orangtua terkendala memfasilitasi sarana kuota untuk belajar anaknya. Untuk kehidupan sehari-hari saja kesulitan, apalagi membeli kuota. Akibatnya siswa tidak bisa mengikuti PJJ dengan maksimal.

Pembelajaran daring kurang maksimal, siswa malas belajar, lengah karena kurang terkontrol. Kurang antusias belajar, siswa butuh komunikasi dan bersosial dengan temannya. Dengan bersosial terjalin interaksi rasa kepedulian, kekeluargaan, kerja sama, dan adanya rasa nyaman. Komunikasi lewat handphone memiliki keterbatasan. Senada pula yang dikemukakan Tantri (2020: 29) bahwa kehadiran sosial dalam pembelajaran daring dinilai sangat penting untuk menghindari besarnya drop out pada pembelajar dikarenakan lingkungan belajar yang didominasi dengan model berbasis teks dan kurang tersedianya simbol-simbol komunikasi nonverbal dan informasi sosioemosional seperti dalam kelas-kelas tatap muka.

Tantri (2020:29) mengemukakan aspek pembelajaran dalam kehadiran sosial, pembelajar merasakan adanya rasa nyaman untuk berinteraksi sesama pembelajar, merasa didorong untuk bertanya, interaksi belajar yang baik, merasa mempunyai waktu belajar yang cukup, menerima umpan balik tepat waktu, perbedaan pendapat, keterbukaan dalam berpendapat, mendapat bantuan belajar dari pembelajar yang lain, kesesuain materi dengan kebutuhan keilmuan, dan dorongan keinginan belajar. 
Disamping itu, meski ekonomi orangtuanya mampu, terdapat siswa malas melakukan PJJ. Tidak membuat tugas, berharap ada toleransi dari pihak sekolah. Permasalahan yang paling urgen adalah rendahnya minat belajar, malas membaca buku dan mengerjakan tugas, kurang motivasi segera mengumpulkan tugas, dan minimnya kebahasaan akibatnya menulis teks khususnya teks eksplanasi mengalami kesulitan. Akibatnya prestasi belajar semakin menurun, ulangan tidak tuntas.

Pembelajaran jarak jauh agar berhasil harus diterapkan secara konsisten, kontinu, terpadu, dan terbimbing agar antara siswa dengan guru harus selalu berinteraksi. Interaksi bisa melalui grup WhatsApp dan aplikasi Geogle Classroom. Google Classroom salah satu aplikasi yang bertujuan untuk membantu guru dan peserta didik berhalangan bertatap muka. Penggantinya menggunakan aplikasi Geogle Classroom. Aplikasi ini bisa mengorganisasi kelas serta berkomunikasi dengan peserta didik tanpa harus terikat dengan jadwal di kelas. Hal ini sependapat dengan Sabran (2020:122) menyatakan dengan menggunakan Google Classroom, maka kemampuan pemecahan masalah siswa mengalami peningkatan serta untuk keefektifan dari penggunaan Google Classroom mendapatkan respons yang positif dari siswa.

Beberapa fasilitas Google Classroom adalah google drive, geogle form, dan geogke docs. Aplikasi ini dapat mendukung proses pembinaan melalui upload atau unggah dan download atau unduh dokumen dalam berbagai format, seperti tugas/materi, pembinaan, dan sharing dokumen. Siswa bisa meningkatkan kualitas pembinaan, mengedit dokumen, memanfaatkan bimbingan kelompok, pemantauan kegiatan belajar siswa, dan fasilitas penyimpanan data. Manfaat lainnya, peserta dapat berinteraksi dengan siswa setiap saat sehingga pekerjaan menjadi praktis, efektif, dan efesien.

Senada pula dengan Dharmawan (2015:47-48) menyatakan google drive sangat praktis, efektif dan efesien, bisa berinteraksi dengan siswa, dapat memantau siswa meski dalam libur, dapat berdiskusi tentang materi pelajaran, dapat memantau kegiatan siswa secara real time dalam kerja kelompok, dan 
dapat menyelesaikan program pembinaan lebih cepat karena tidak terpaku pada pertemuan kelas.

Berdasarkan latar belakang yang dikemukakan di atas, rumusan masalah yang akan dijawab yaitu: 1) Seberapa tinggi hasil pembelajaran menulis teks eksplanasi siswa sebelum diterapkannya model aksi insiden berbasis classroom pada pada masa pandemi Covid-19?, 2) Seberapa tinggi hasil pembelajaran menulis teks eksplanasi siswa setelah diterapkannya model aksi insiden berbasis classroom pada masa pandemi Covid-19?, 3) Seberapa besar pengaruh hasil pembelajaran model aksi insiden berbasis classroom dalam meningkatkan kemampuan menulis teks eksplanasi siswa pada masa pandemi Covid-19?, dan 4) Bagaimanakah respons siswa terhadap penerapan model aksi insiden berbasis classroom dalam meningkatkan kemampuan menulis teks eksplanasi siswa pada masa pandemi Covid-19?

Beberapa tujuan penelitian ini, yaitu: 1) mendeskripsikan seberapa tinggi hasil pembelajaran menulis teks eksplanasi sebelum diterapkannya model aksi insiden berbasis classroom pada masa pandemi Covid-19; 2) mendeskripsikan seberapa tinggi hasil pembelajaran menulis teks eksplanasi siswa setelah diterapkannya model aksi insiden berbasis classroom pada masa pandemi Covid19; 3) mendeskripsikan seberapa besar pengaruh hasil pembelajaran model aksi insiden berbasis classroom dalam meningkatkan kemampuan menulis teks eksplanasi siswa pada masa pandemi Covid-19; dan mendeskripsikan respons siswa terhadap penerapan model aksi insiden berbasis classroom dalam meningkatkan kemampuan menulis teks eksplanasi siswa pada masa pandemi Covid-19.

Dipilihnya materi menulis teks eksplanasi karena siswa sebagian besar masih kesulitan dalam menungkan ide dan menuliskannnya dalam bentuk paragraf eksplanasi terutama sesuai dengan ciri teks paragraf eksplanasi. Teks eksplanasi merupakan sebuah teks yang berisi tentang proses-proses yang berhubungan dengan fenomena-fenomena alam, sosial, ilmu pengetahuan, budaya, dan lain sebagainya (Mahsuh, 2014:189). Ciri-ciri teks eksplanasi yang belum dikuasai siswa yaitu: 1) strukturnya terdiri dari pernyataan umum, urutan 
sebab akibat, dan interpretasi; 2) memuat informasi berdasarkan fakta "faktual"; dan 3) faktualnya itu memuat informasi yang bersifat ilmiah atau keilmuan seperti sains dan yang lainnya (Mahsun, 2014). Dengan diterapkannya model aksi insiden berbasis classroom diharapkan terjadi peningkatan kemampuan menulis teks eksplanasi siswa.

Dengan pelaksanaan penelitian ini, diharapkan bermanfaat khusunya bagi siswa, yaitu pembelajaran menjadi lancar karena dilakukan secara kelompok. Tercipta rasa kepedulian, kerja sama, nyaman dalam belajar. Siswa bertanggung jawab dengan sungguh-sungguh, mengerjakan tugasnya, serta cepat mengumpulkan tugasnya, hasil yang diperoleh maksimal. Sedangkan manfaat bagi guru dapat mengembangkan strategi pembelajaran yang tepat, mengatasi permasalahan dalam proses belajar mengajar, mengembangkan keprofesionalan dalam tugas, melalui inovasi dalam proses pembelajaran, serta meningkatkan kreativitas guru dalam mengelola kegiatan pembelajaran.

Pembelajaran classroom salah satu aplikasi alternatif yang sangat cocok digunakan masa pandemi covid-19. Aplikasi ini bisa mengkoordinir kelas secara keseluruhan. Bisa memberikan tugas kepada siswa secara klasikal walau tidak bertatap muka. Penggunaan aplikasi classroom identik dengan belajar tatap muka. Siswa jika kurang paham bisa bertanya kepada gurunya lewat kolom komentar. Hal ini senada dengan Nirfayanti \& Nurbaeti (2019:51) menyatakan Google Classroom merupakan sebuah aplikasi yang memungkinkan terciptanya ruang kelas di dunia maya.

Aplikasi Google Classroom dapat digunakan oleh siapa saja yang tergabung dengan kelas tersebut yang didesain oleh guru, seperti belajar kelas nyata di sekolah. Namun, diperlukan serangkaian alat produktivitas gratis seperti gmail, dokimen, dan drive. Gunawan \& Sunarman (2018:341) menyatakan salah satu cara yang dapat digunakan untuk melakukan proses pembelajaran secara daring adalah dengan menggunakan Google Classroom. Pemanfaatan Google Classroom dapat melalui multiplatform yakni dapat melalui komputer dan dapat melalui gawai. Melalui aplikasi Google Classroom diasumsikan bahwa tujuan pembelajaran akan lebih mudah direalisasikan dan sarat kebermaknaan. Oleh 
karena itu, penggunaan Google Classroom ini sesungguhnya mempermudah guru dalam mengelola pembelajaran dan menyampaikan informasi secara tepat dan akurat kepada siswa. Google Classroom adalah ruang, tempat untuk belajar guru dan siswa tanpa tatap muka secara langsung.

Aplikasi lain yang sangat mendukung dalam pembuatan tugas siswa adalah geogle docs. Geogle docs ibarat buku tulis, tempat siswa mengerjakan tugas yang diberikan guru. Geogle docs ini bisa diedit oleh guru maupun siswa. Dharmawan dkk. (2015:46) menyuatakan google docs adalah salah satu aplikasi yang dikembangkan Google untuk kebutuhan file server. Khususnya aplikasi office. Mulai dari pengolah kata, pengolah lembar kerja dan presentasi. Google docs dapat juga bisa digunakan untuk untuk mengolah (menyimpan, membuat, mengedit) program-program aplikasi perkantoran secara online.

Menurut Weier (2010) (dalam Dharmawan, 2015), ada beberapa kelebihan google docs antara lain: mudah digunakan, tidak bayar (gratis), menghindari data hilang akibat kerusakan harddisk, support dan dokumentasinya lengkap, menggunakan editor WYSIWYG (What You See Is What You Get) yang sederhana untuk memformat dokumen, memeriksa ejaan, dan sebagainya. Sedangkan berdasarkan hasil penelitian Nirfayanti \& Nirfayanti (2019:58) disimpulkan bahwa terdapat pengaruh yang signifikan media pembelajaran Google Classroom terhadap motivasi belajar mahasiswa semester $\mathrm{V}$ Program Studi Pendidikan Matematika FKIP Universitas Muslim Maros.

Ayuni (2020:415) juga menyatakan bahwa pembelajaran daring dapat berjalan dengan efektif, diperlukakan persiapan oleh pihak sekolah, dan orangtua wali murid. Pihak sekolah memberikan fasilitas kepada guru berupa perangkat laptop atau hanphone (gawai) kepada guru dan paket internet yang diperlukan. Sedangkan pihak orangtua mempersiapkan perangkat handphone dan paket internet serta pendampingan terhadap putra putrinya.

Mustofa dkk., (2019:154) mengadaptasi pendapat Khoe Yao Tung (2020: 15), menyampaikan karakteristik pembelajaran daring, antara lain: 1) materi ajar disajikan dalam bentuk teks, grafik, dan berbagai elemen multimedi, 2) komunikasi dilakukan secara serentak dan tak serentak seperti video conferencing, chats 
rooms, atau discussion forum, 3) digunakan untuk belajar pada waktu dan tempat maya, 4) dapat digunakan berbagai elemen belajar berbasis CD-Rod, 5) kemungkinkan bentuk komunikasi belajar formal dan informal, dan 6) dapat menggunakan ragam sumber belajar yang luas di internet.

Keberhasilan pembelajaran daring ditentukan pula dengan kesiapan guru. Kesiapan tersebut seperti rencana pembelajaran, materi-materi pembelajaran yang akan disampaikan, media pembelajaran, mengatur jadwal pembelajaran daring, membuat power point, dan soal-soal dalam bentuk geogle form. Persiapan ini harus direncanakan jauh hari maksimal sehari sebelum mengajar harus sudah disiapkan. Pembelajaran daring berbeda dengan belajar tatap muka yang bisa sukses hanya kehadiran gurunya saja. IImu yang sudah terekam dalam memori guru bisa langsung ditransfer kepada siswa. Penyampaiannya tentu dengan metode andalan guru yang bersangkutan. Sementara itu, pembelajaran daring harus mempersiapkan semau perangkat yang dibutuhkan. Tanpa persiapan pembelajaran daring kurang maksimal hasilnya.

Dewi (2020:58) mengemukakan pembelajaran daring dilakukan dengan disesuaikan kemampuan masing-masing sekolah. Belajar daring (online) dapat menggunakan teknologi digital seperti Google Classroom, Rumah Belajar, Zoom, telepon atau live chat, dan lainnya. Namun, yang pasti harus dilakukan adalah pemberian tugas melalui pemantauan pendampingan oleh guru melalui WhatsApp grup sehingga anak betul-betul belajar. Kemudian, guru-guru juga bekerja dari rumah dengan berkoordinasi dengan orang tua, bisa melalui video call maupun foto kegiatan belajar anak di rumah untuk memastikan adanya interaksi antara guru dengan orang tua.

Berdasarkan pendapat pakar di atas, dapat dirangkum bahwa pembelajaran daring dapat dilaksanakan dengan baik. Pandemi Covid-19 bukan penghalang untuk meningkatkan mutu pendidikan. Oleh sebab itu, banyak cara yang harus dilakukan oleh guru. Semuanya berdasarkan komitmen dan tanggung jawab guru menjalankan tugas profesionalnya.

Dari beberapa penelitian yang relevan terkait dengan model aksi insiden dan Google Calssroom maka peneliti mengkombinasikannya menjadi model asi 
insiden berbasis classromm sebagai alternatif dalam meningkatkan kemampuan menulis teks eksplanasi siswa pada masa pandemi Covid-19. Pembelajaran model aksi insiden ini merupakan rangkaian pembelajaran yang menggunakan perangkat internet, aplikasi Google Classroom, geogle docs, geogle form, drive. Pembelajaran model ini dilakukan secara kelompok. Berikut gambaran kerangka pemikiran munculnya ide model aksi insiden.

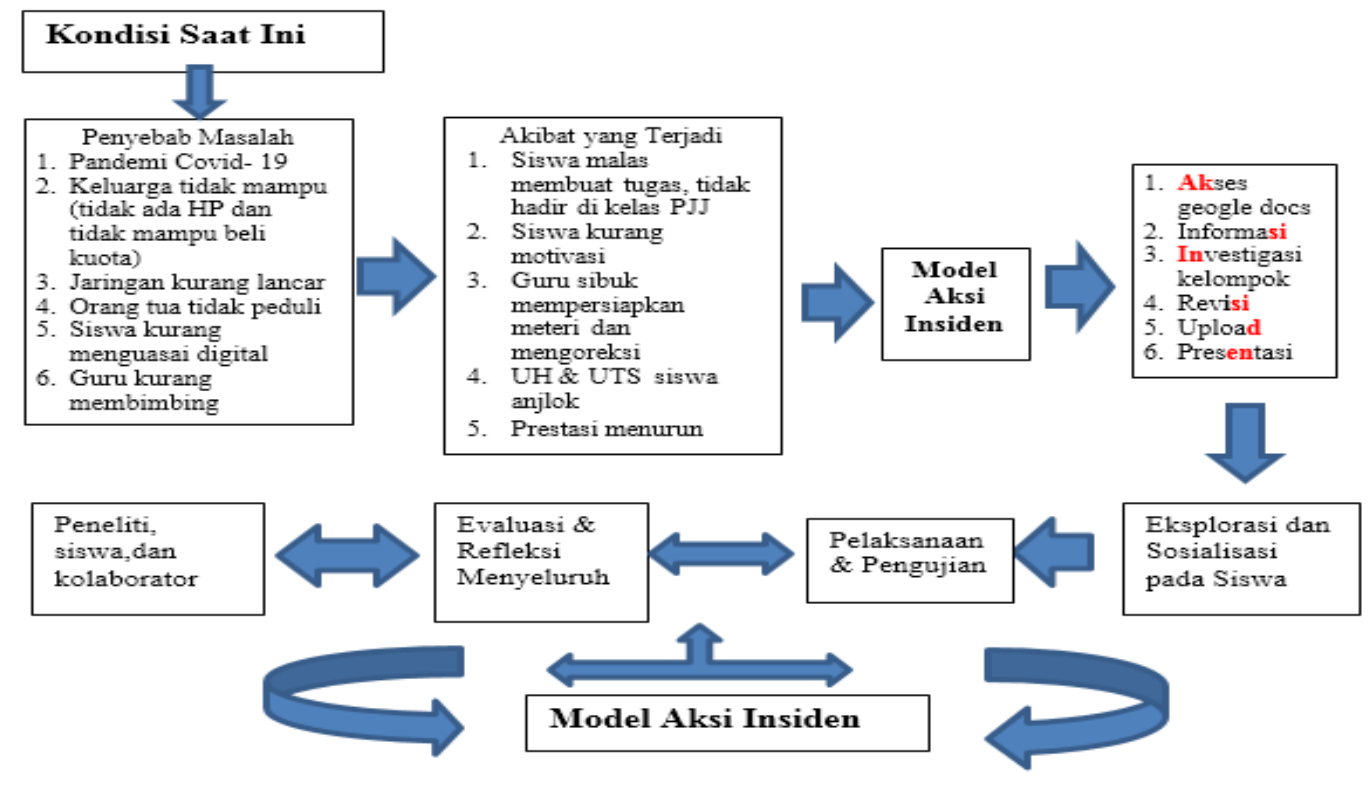

Gambar 1. Kerangka Pemikiran

Istilah "aksi insiden" merupakan akronim dari $\mathbf{a} \boldsymbol{k}=\mathbf{a k s e s}$ (ketua kelompok mengakses kelompok dengan aplikasi geogle doc.), si = instruksi (guru memberikan perintah lewat WA dan classroom), In = investigasi kelompok (tugas dilaksanakan dengan sistem siswa wajib menyumbang ide), si = revisi (ketua kelompok merevisi, anggota memberi masukan untuk penyempurnaan), $\mathbf{d}=$ upload (tugas diunggah ke classroom untuk diperiksa guru), dan en = presentasi (hasil akhir dipresentasikan secara individu dengan direkam dan diuggah ke classroom).

\section{B. Metode Penelitian}

Metode penelitian yang digunakan yaitu metode Penelitian Tindakan Kelas (PTK) yang dilakukan menggunakan model Kemmis dan Mc Taggart dalam bentuk diagram alir. Tindakan dilakukan dua siklus, setiap siklus 2 kali pertemuan 
melalui pembelajaran daring dengan aplikasi Google Classroom, geogle form, geogle docs, dan WhatsApp. Materi 6 kali pertemuan, tes awal pertemuan pertama, kemudian pertemuan siklus 1 dan 2, diakhiri tes. Subjek siswa SMAN 8 Kota Bengkulu, kelas XI IPA 1 sebanyak 32 orang, dengan rincian perempuan 23 orang dan laki-laki 9 orang. Sumber data siswa, untuk mendapatkan data tentang hasil belajar dan respons siswa dalam proses belajar mengajar.

Teknik pengumpulan data menggunakan: 1) tes: untuk mendapatkan data tentang hasil belajar menulis teks eksplanasi siswa, pengaruh penggunaan model aksi insiden, dan 2) nontes: untuk mendapatkan data respons siswa terhadap model aski insiden dalam pembelajaran. Alat pengumpul data melalui 1) tes: menggunakan butir soal pilhan ganda dan esai untuk mengukur hasil belajar menulis teks eksplanasi siswa, dan 2) kuesioner: untuk mengetahui respons siswa terhadap model aksi insiden dalam pembelajaran.

Teknik analisis data dengan data kualitatif dan kuantitatif. Data kualitatif adalah data yang tidak dapat diukur secara langsung, cenderung berbasis katakata atau kalimat. Data penelitian ini diperoleh melalui angket. Data dianalisis dengan statistik deskriptif, dengan rumus sebagai berikut ini.

Keterangan:

$$
\mathrm{P}=\frac{f}{N} X 100 \%
$$

$P$ : Persentase

$f$ : Frekuensi aktivitas siswa

$\mathrm{N}$ : Jumlah skor responden (skor ideal)

Untuk mengukur dan menilai data yang diperoleh, peneliti menggunakan skala pengukuran Skala Likert. Skala Likert digunakan untuk mengukur respons siswa terhadap penerapan model aksi insiden. Berupa item-item pernyataan sangat setuju (5), setuju (4), ragu-ragu (3), tidak setuju (2), dan sangat tidak setuju (1). Pernyataan 'Sangat Setuju dan Setuju'. Misalnya seluruh siswa menjawab angket pernyataan "Sangat Setuju dan Setuju" berjumlah 280, skor ideal keseluruhan adalah 640 (20 item X 32 siswa). Berarti skor angket secara keseluruhan yang diperoleh untuk respon siswa "Setuju" adalah 280/640 X 
$100 \%=43,75 \%$. Rumus untuk pengkategorian hasil belajar dan respons siswa berdasarkan tabel 1.

Tabel 1. Pengkategorian Hasil Belajar Menulis Teks Eksplanasi dan Respons Siswa terhadap Model Aksi Insiden

\begin{tabular}{ll}
\hline Klasifikasi & Kategori \\
\hline $81-100 \%$ & Sangat Baik \\
\hline $61-80 \%$ & Baik \\
\hline $41-60 \%$ & Cukup \\
\hline$<40 \%$ & Kurang \\
\hline
\end{tabular}

Data kuantitatif adalah data yang dapat diklasifikasikan, konkret, teramati dan terukur, cenderung berbasis angka-angka. Data kuantitatif diperoleh melalui tes, menggunakan deskripsi persentase. Data yang dikumpulkan pada setiap kegiatan observasi dari pelaksanaan siklus penelitian dianalisis secara deskriptif dengan menggunakan teknik persentase untuk melihat kecenderungan yang terjadi dalam kegiatan pembelajaran. Hasil belajar menulis teks eksplanasi dengan menganalisis nilai rata-rata tes setiap siklus. Kemudian dikategorikan dalam klasifikasi sangat baik, baik, cukup, dan kurang.

Langkah-langkah praktis PTK berdasarkan tindakan nyata yang dilakukan guru. Tindakan kelas masa pandemi Covid-19 ini, berbeda dengan tindakan tatap muka secara langsung. Namun prosedur, langkah-langkah masih berlaku seperti pembelajaran normal.

Menurut Susilowati (2018:40-41) prinsip dalam PTK antara lain: 1) terlihat adanya upaya untuk meningkatkan mutu professional guru, 2) tampak dalam unjuk kerja siswa, 3) seluruh siswa dalam suatu kelas terlibat, 4) permasalahan muncul di kelasnya, 5) penelitian berlangsung dalam siklus, 6) penelitiannya tentang cara, prosedur, metode atau strategi, 7) tindakan yang diberikan berbeda dari biasanya, 8) tindakan berpijak dari kondisi nyata, 9) tindakan merupakan kesepakatan bersama antara guru dan siswa, 10) terdapat pengamatan oleh kolaborator atau teman sejawat, 11) terdapat evaluasi hasil sebagai konsekuensi dari proses, 12) penerapan instrumen sesuai indikator, dan 13) refleksi dilakukan sebagai perenungan bersama atas tindakan dan hasil yang dicapai.

Langkah-langkah praktis pelaksanaan PTK dijabarkan dalam tulisan ini. Fokus kegiatan dalam pembelajaran antara lain: (1) planning, (2) acting, (3) 
observing, dan (4) reflecting. Kegiatan-kegiatan ini disebut satu siklus kegiatan pemecahan masalah. Bila satu siklus belum menunjukkan tanda-tanda perbaikan (peningkatan mutu), kegiatan riset dilanjutkan pada siklus kedua, dan seterusnya.

Tabel 2. Jadwal Pelaksaanaan Siklus

\begin{tabular}{|c|c|c|c|c|c|c|}
\hline Tanggal & $\begin{array}{l}\text { Pertemuan } \\
\text { Ke- }\end{array}$ & Siklus Ke- & Kegiatan & Materi & Model & $\begin{array}{c}\text { Jenis } \\
\text { Tes }\end{array}$ \\
\hline $25 / 8 / 20$ & $\begin{array}{c}\text { Pertemuan } \\
1\end{array}$ & Tes awal & Tes awal & $\begin{array}{l}\text { Tes PG struktur } \\
\text { Teks Eksplanasi }\end{array}$ & $\begin{array}{l}\text { Konvensional } \\
\text { Individu }\end{array}$ & $\begin{array}{l}\text { Pilihan } \\
\text { Ganda }\end{array}$ \\
\hline $26 / 8 / 20$ & $\begin{array}{c}\text { Pertemuan } \\
2\end{array}$ & $\begin{array}{l}\text { Siklus 1, } \\
\text { Pertemuan } \\
1\end{array}$ & $\begin{array}{l}\text { 1. Catat di } \\
\text { buku } \\
\text { 2. Foto } \\
\text { 3. Kirim GCR }\end{array}$ & $\begin{array}{l}\text { Mengindetifikasi } \\
\text { Struktur Teks } \\
\text { Eksplanasi }\end{array}$ & $\begin{array}{l}\text { Konvensional } \\
\text { Individu }\end{array}$ & Esai \\
\hline $1 / 9 / 20$ & $\begin{array}{c}\text { Pertemuan } \\
3\end{array}$ & $\begin{array}{l}\text { Siklus 1, } \\
\text { Pertemuan } \\
2\end{array}$ & $\begin{array}{l}\text { 1. Catat di } \\
\text { buku } \\
\text { 2. Foto } \\
\text { 3. Kirim GCR }\end{array}$ & $\begin{array}{l}\text { Menelaah } \\
\text { Kebahasaan Teks } \\
\text { Ekplanasi }\end{array}$ & $\begin{array}{l}\text { Konvensional } \\
\text { Individu }\end{array}$ & Esai \\
\hline $7 / 9 / 20$ & $\begin{array}{c}\text { Pertemuan } \\
4\end{array}$ & $\begin{array}{l}\text { Siklus } 2 \\
\text { Pertemuan } \\
1\end{array}$ & $\begin{array}{l}\text { 1. Ketik di } \\
\text { docs } \\
\text { 2. Kirim GCR }\end{array}$ & $\begin{array}{l}\text { Membuat } \\
\text { kerangka teks } \\
\text { eksplanasi }\end{array}$ & $\begin{array}{l}\text { Aksi Insiden } \\
\text { Kelompok }\end{array}$ & Esai \\
\hline $8 / 9 / 20$ & $\begin{array}{c}\text { Pertemuan } \\
5\end{array}$ & $\begin{array}{l}\text { Sikkus 2 } \\
\text { Pertemuan } \\
2\end{array}$ & $\begin{array}{l}\text { 1. Ketik di } \\
\text { docs } \\
\text { 2. Kirim GCR }\end{array}$ & $\begin{array}{l}\text { Mengembangkan } \\
\text { Teks Eksplanasi }\end{array}$ & $\begin{array}{l}\text { Aksi Insiden } \\
\text { Kelompok } \\
\text { dan Individu }\end{array}$ & Esai \\
\hline $14 / 9.20$ & $\begin{array}{c}\text { Pertemuan } \\
6\end{array}$ & Tes Akhir & Tes Akhir & $\begin{array}{l}\text { Tes PG struktur } \\
\text { dan Kebahasaan } \\
\text { Teks Eksplanasi }\end{array}$ & Individu & $\begin{array}{l}\text { Pilihan } \\
\text { Ganda }\end{array}$ \\
\hline
\end{tabular}

\section{Hasil Penelitian dan Pembahasan}

\section{Hasil Penelitian}

\section{a. Prasiklus (Pertemuan 1)}

Guru melakukan tes awal dengan memberikan materi bentuk Ms. Word ke Grup Classroom (GCR) dan soal geogle from pilihan ganda sebanyak 10 soal. Dalam forum GCR memberikan petunjuk secara umum. Rata-rata hasil belajar mencapai 73, 44 \%. Hal ini siswa masih belum mengenal struktur teks eksplanasi secara gamblang. Hasil yang diperoleh tercantum pada tabel 3.

\section{b. Siklus 1}

\section{1) Pertemuan 1}

Perencanaan yang dipersiapkan antara lain: 1) mengkonsep strategi materi PJJ yang akan diajarkan, 2) merancang langkah kerja pembelajaran, 3) menentukan nama model pembelajaran menarik, 4) membuat RPP KD yang akan 
diajarkan, 5) menyusun materi pertemuan ke-1, 6) menyusun evaluasi, dan 7) membuat Power Point, dan mengirim ke Youtube.

Pelaksanaan tindakan, guru memberikan materi Mengidentifikasi Struktur Teks Eksplanasi melalui video Power Point, setelah itu siswa diberi soal esai, buku paket halaman 63 teks Demontrasi Massa lewat GCR. Pertemuan ini siswa belajar secara individu dengan mencatat di buku, hasil pekerjaan di foto, kemudian dikirim ke GCR.

Hasil kerja siswa diobservasi dan dievauasi, rata-rata hasil belajar mencapai $70,81 \%$. Pada tahap ini siswa belum fokus belajar daring, terdapat 6 orang belum masuk kelas karena tidak ada kuota dan kurang paham belajar daring.

Refleksi yang diperoleh, siswa kurang fokus dalam belajar. Enam orang siswa belum masuk kelas, guru mengingatkan siswa lewat grup WhatsApp agar pertemuan mendatang harus aktif.

\section{2) Pertemuan 2}

Perencanaan sama seperti siklus sebelumnya, guru mempersiapkan materi untuk pertemuan berikutnya serta evaluasi yang diberikan. Pelaksanaan tindakan, guru memberi materi Menelaah Kebahasaan Teks Eksplanasi menggunakan buku paket halaman 64-65 teks Demontrasi Massa lewat GCR. Siswa mengerjakan soal esai, membuat 5 kalimat dengan menggunakan konjungsi. Pertemuan ini siswa belajar secara individu dengan mencatat di buku, hasil pekerjaan di foto, kemudian dikirim ke GCR.

Hasil kerja siswa diobservasi dan dievaluasi, rata-rata hasil belajar mencapai rata-rata hasil belajar mencapai $85,78 \%$. Pembelajaran meningkat tajam karena siswa sudah pandai membuat paragraf teks eksplanasi dengan menggunakan konjungsi.

Refleksi yang yang diperoleh, masih ada 1 orang siswa tidak masuk kelas. Guru mengingatkan siswa lewat grup WhatsApp agar pertemuan mendatang harus hadir lengkap karena pertemuan berikutnya dilakukan secara kelompok. Jika salah satu temannya tidak hadir akan mempengaruhi poin kelompok. 


\section{c. Siklus 2}

\section{1) Pertemuan 1}

Perencanaan yang dipersiapkan guru mempersiapkan materi, membuat daftar kelompok, memantapkan strategi penerapan model aksi insiden, membuat evaluasi. Pelaksanaan tindakan, guru memberikan informasi ke grup dan membagikan daftar kelompok sehari sebelum pembelajaran. Mengirim tugas ke GCR tentang membuat kerangka teks eksplanasi dan mengirimkan langkahlangkah/instruksi (petunjuk umum dan khusus, serta format kerja yang disediakan guru).

Hasil kerja siswa diobservasi dan dievaluasi, rata-rata hasil belajar mencapai 89, $25 \%$, siswa mulai fokus belajar daring, semua siswa antusias bekerja menyumbang dua gagasan ke dalam geogle dokumen dengan warna berbeda yang sudah ditentukan guru. Guru mengamati proses pembelajaran, siswa konsultasi lewat whatsApp, mengontrol siswa yang rajin konsultasi.

Refleksi yang yang diperoleh, hasil belajar meningkat karena bekerja secara kelompok. Guru merancang strategi berikutnya, saat pengembangan teks ekplanasi kembali secara individu kembali. Guru mengingatkan siswanya lewat grup WhatsApp agar pertemuan besok harus siap-siap mengembangkan kerangka karangan.

\section{2) Pertemuan 2}

Perencanaan yang dipersiapkan guru mempersiapkan materi, memantapkan strategi penerapan model aksi insiden, membuat evaluasi. Pelaksanaan tindakan, guru memberikan informasi ke grup. Mengirim tugas ke GCR tentang mengembangkan kerangka teks eksplanasi dan mengirimkan langkahlangkah/instruksi (petunjuk umum dan khusus, serta format kerja yang disediakan guru).

Hasil kerja siswa diobservasi dan dievaluasi, rata-rata hasil belajar mencapai 86, $78 \%$, nilai mengalami penutunan karena pengembangan karangan dilakukan secara individu, namun hasilnya masih kategori sangat bagus. Siswa sudah fokus belajar daring, antusias bekerja menyempurnakan tugas masing-masing. Guru 
mengamati proses pembelajaran, siswa konsultasi lewat WhatsApp, dan mengontrol siswa yang rajin konsultasi.

Refleksi yang yang diperoleh, hasil belajar sangat bagus, setelah bekerja kelompok, siswa melanjutkan tugasnya secara individu. Guru bersiap-siap membuat soal tes akhir dan kuesioner untuk menguji model aksi insiden.

Tabel 3. Rata-Rata Hasil Belajar Prasiklus hingga Siklus 1, 2 Model Aksi Insiden

\begin{tabular}{|c|c|c|c|c|c|c|c|c|}
\hline \multirow{3}{*}{ NO } & \multirow{3}{*}{ NAMA } & \multicolumn{7}{|c|}{ NILAI KD 3.2 (IFEKS EKSPLANA SI) MODEL AKSI INSIDEN } \\
\hline & & Tes Awal & SIklus $1\{1\}$ & SIklus 1 [2] & siklua $2(1)$ & Slkius $2(2)$ & TeB Akhlr & Praktik \\
\hline & & 25-Agu & 26-Agu & d1-Sep & 07-sep & Os-Sep & 14-Sep & 10 -Sep \\
\hline 1 & AFD & 65 & 90 & 90 & 88 & 85 & 88 & 85 \\
\hline 2 & AYM & 65 & 90 & 95 & 88 & 90 & 91 & 90 \\
\hline 3 & SADP & 65 & 90 & 95 & 88 & 90 & 91 & 90 \\
\hline 4 & APS & 60 & 85 & 88 & 88 & 90 & 88 & 90 \\
\hline 5 & ASP & 65 & 0 & 90 & 90 & 85 & 66 & 85 \\
\hline 6 & ATE & 100 & 85 & 90 & 90 & 87 & 88 & 87 \\
\hline 7 & DNS & 80 & 90 & 90 & 90 & 88 & 90 & 88 \\
\hline 8 & $\mathrm{DI}$ & 70 & 85 & 90 & 90 & 85 & 88 & 85 \\
\hline 9 & $\mathrm{DHS}$ & 65 & 85 & 88 & 90 & 90 & 88 & 90 \\
\hline 10 & $\mathrm{DAN}$ & 65 & 88 & 83 & 90 & 85 & 87 & 85 \\
\hline 11 & DRF & 65 & 88 & 90 & 90 & 85 & 88 & 85 \\
\hline 12 & ES & 65 & 87 & 90 & 90 & 86 & 88 & 86 \\
\hline 13 & GSS & 65 & 90 & 90 & 90 & 90 & 90 & 90 \\
\hline 14 & $-\mathrm{HN}$ & 90 & 82 & 85 & 90 & 85 & 86 & 85 \\
\hline 15 & $\angle B A$ & 100 & 86 & 85 & 90 & 88 & 87 & 88 \\
\hline 16 & $-P_{1}$ & 80 & 88 & 90 & 88 & 88 & 89 & 88 \\
\hline 17 & MRM & 70 & 0 & 90 & 90 & 85 & 66 & 85 \\
\hline 18 & MAN & 80 & 87 & 88 & 88 & 90 & 88 & 90 \\
\hline 19 & MNP & 65 & 85 & 85 & 88 & 85 & 86 & 85 \\
\hline 20 & MAN & 65 & 0 & 0 & 88 & 83 & 43 & 83 \\
\hline 21 & MRM & 65 & 0 & 90 & 90 & 85 & 66 & 85 \\
\hline 22 & $\mathrm{NCO}$ & 100 & 86 & 85 & 90 & 87 & 87 & 87 \\
\hline 23 & NAA & 90 & 0 & 83 & 88 & 85 & 64 & 85 \\
\hline 24 & PK & 80 & 86 & 83 & 90 & 85 & 86 & 85 \\
\hline 25 & FF & 65 & 90 & 90 & 90 & 85 & 89 & 85 \\
\hline 26 & $\mathrm{FH}$ & 65 & 0 & 90 & 90 & 85 & 66 & 85 \\
\hline 27 & $\mathrm{FAH}$ & 70 & 85 & 90 & 88 & 85 & 87 & 85 \\
\hline 28 & SDAS & 90 & 86 & 90 & 88 & 90 & 89 & 90 \\
\hline 29 & SAR & 90 & 85 & 86 & 90 & 87 & 87 & 87 \\
\hline 30 & SNR & 65 & 90 & 90 & 90 & 87 & 89 & 87 \\
\hline 31 & TAR & 60 & 87 & 86 & 88 & 90 & 88 & 90 \\
\hline \multirow[t]{3}{*}{32} & VA & 65 & 90 & 90 & 90 & 86 & 89 & 86 \\
\hline & fumian & 2350 & 2266 & 2745 & 2856 & 2777 & 2661 & 2777 \\
\hline & Rata2 & 73,44 & 70,81 & 85,78 & 89,25 & 86,78 & 83,16 & 86,78 \\
\hline
\end{tabular}

\section{d. Tes Akhir}

Hasil pembelajaran dengan model aksi insiden berbasis classroom hasil pekerjaan siswa bagus, tugas dikumpulkan cepat, siswa menjadi disiplin dan termotivasi, serta bertanggung jawab menyelesaikan tugasnya. Proses 
pembelajaran mengalami peningkatan dari siklus 1 ke siklus 2 sebesar $1 \%$. Ratarata kelas memperoleh 83,16\%, termasuk kategori "Sangat Baik".

\section{e. Pengaruh Penggunaan Model Aksi Insiden}

Hasil belajar sebelum menerapkan model aksi insiden rata-rata 73,44\% dikategorikan "Baik". Sedangkan sesudah menerapkan model aksi insiden diperoleh kategori "Sangat Baik" dengan rata-rata 83,16\% dikategorikan "Sangat Baik". Hasil siklus 1 ke 2 mengalami kenaikan 1\%. Pengaruh penerapan model aksi insiden mengalami peningkatan 9,72\%. Hal ini menyatakan model aksi insiden sangat berpengaruh dalam pembelajaran.

\section{f. Respons Siswa terhadap Model Aksi Insiden}

Hasil angket diperoleh 63,75\% siswa setuju model aksi insiden berbasis classroom diterapkan masa pandemi Covid-19, diperoleh kategori "Baik".

\section{Pembahasan}

Penerapan model aksi insiden berbasis classroom mampu meningkatkan kemampuan menulis teks eksplanasi pada masa pandemi Covid-19. Hal ini ditunjukkan dengan sebelum menerapkan model aksi insiden siswa memperoleh hasil belajar dengan nilai rata-rata sebesar 73,44 dengan kategori baik dan meningkat sesudah diterapkannya model aksi insiden dengan nilai rata-rata sebesar 83,16 dengan kategori sangat baik. Model aksi insiden berbasis classroom memiliki kelebihan mampu meningkatkan kreativitas siswa ketika proses kegiatan menulis teks eksplanasi karena setiap individu dalam kelompok menyumbangkan idenya dalam bentuk tulisan eksplanasi. Dalam kegiatan menulis teks eksplanasi, kreativitas siswa terbangun dengan siswa mengerjakan proyek tulisan eksplanasi secara investigasi (menyumbang ide), siswa melaksanakan kewajibannya dengan mengisi format yang disediakan ketua kelompok dengan warna tinta berbeda, pengiriman tugas otomatis tercantum dalam geogle dokumen, dan dapat dilihat bersama-sama.

Dengan penerapan model aksi insiden berbasis classroom siswa sudah mampu menulis teks eksplanasi sesuai dengan ciri-ciri teks eksplanasi terutama pada siklus ke-2. Ciri-ciri teks eksplanasi menurut Mahsun (2014), yaitu: 
1) strukturnya terdiri dari pernyataan umum, urutan sebab akibat, dan interpretasi;

2) memuat informasi berdasarkan fakta "faktual"; dan 3) faktualnya itu memuat informasi yang bersifat ilmiah atau keilmuan seperti sains dan yang lainnya.

Sebelum diterapkannya model aksi insiden berbasis classroom, siswa masih kesulitan menulis teks eksplanasi karena minimnya penguasaan kebahasaan dan perbendaharaan kata, akibat malas membaca (Sari dkk., 2020). Terutama masa pandemi ini, malas membaca semakin bertambah. Masyarakat tidak boleh berkerumun, harus jaga jarak, mematuhi protokol kesehatan akibatnya pendidikan tidak berjalan normal. Otomatis dunia pendidikan menjadi imbas. Meskipun pandemi covid- 19, pendidikan harus berjalan agar mutu pendidikan tidak merosot. Oleh sebab itu pemerintah mengeluarkan surat edaran Sekjen Kementerian P \& K No. 15 tahun 2020 tentang pedoman penyelenggaraan belajar dari rumah dalam masa darurat penyebaran Covid-19.

Penulis mencari ide model inovasi Pembelajaran Jarak Jauh (PJJ) atau school from home, akhirnya muncullah ide model aksi insiden berbasis classroom sekaligus dijadikan penelitian tindakan kelas (PTK). PTK ini menerapkan pembelajaran daring berbasis classroom dengan menggunakan aplikasi geogle docs, geogle form, drive, dan alat komunilasi WhatsApp.

Mulia \& Suwarno (2016) menyatakan penelitian tindakan kelas merupakan kegiatan mencermati suatu objek dengan menggunakan aturan metodologi tertentu untuk memperoleh data dan informasi yang bermanfaat dalam meningkatkan mutu suatu hal, serta menarik minat dan penting bagi peneliti. Tindakan adalah kegiatan yang sengaja dilakukan dengan tujuan tertentu, sedangkan kelas adalah sekelompok siswa yang dalam waktu yang sama menerima pelajaran yang sama dari seorang guru (Arikunto, 2006). Adapun menurut Kunandar (2008), PTK merupakan penelitian tindakan yang dilakukan oleh guru sekaligus sebagai peneliti di kelasnya atau bersama-sama dengan orang lain (kolaborasi) dengan jalan merancang, melaksanakan, dan merefleksikan tindakan secara kolaboratif dan partisipatif yang bertujuan untuk memperbaiki atau meningkatkan kualitas proses pembelajaran di kelasnya melalui suatu tindakan tertentu dalam suatu siklus. 
Kesulitan menulis teks eksplanasi dapat diatasi dengan model aksi insiden, karena dikerjakan serentak (proyek bersama) mulai dari merancang kerangka, mengembangkan gagasan sehingga menjadi teks utuh, meski teksnya belum sempurna. Guru menyuruh siswa merevisi secara individu. Boleh diubah susunannya, dibuang atau ditambah gagasannya, pekerjaannya tidak boleh sama.

Defenisi aksi insiden adalah model pembelajaran variatif secara kelompok dan individu berbasis classroom mengerjakan proyek tulisan secara investigasi (menyumbang ide), siswa melaksanakan kewajibannya dengan mengisi format yang disediakan ketua kelompok dengan warna tinta berbeda, pengiriman tugas otomatis tercantum dalam geogle dokumen, dan dapat dilihat bersama-sama.

Langkah-langkah inovasi guru yang sesuai dengan silabus khusus PJJ adalah: 1) mengkonsep strategi materi PJJ yang akan diajarkan, 2) merancang langkah kerja pembelajaran, 3) menentukan nama model pembelajaran menarik, 4) membuat RPP KD yang akan diajarkan, 5) menyusun materi pertemuan pertama dan kedua, 6) menyusun evaluasi, 7) membuat power point, mengirimnya ke Youtube, 8) membagi kelompok, 8) sehari sebelum pertemuan, guru membagikan petunjuk tugas ke WA, 9) menerapkan model aksi insiden, mengirimkan tugas ke classroom, 10) membimbing lewat WA, 11) menilai hasil upload, dan 12) refleksi.

Respons siswa "Setuju" terhadap penerapan model aksi insiden berbasis classroom. Rata-rata perolehan $63,75 \%$, menyatakan setuju dan termasuk kategori "Baik". Pembelajaran berjalan lancar, siswa saling mengingatkan temannya agar tugas kelompok tersebut anggotanya lengkap. Kelengkapan anggota sangat menentukan hasil kerja karena setiap anggota harus menyumbang pemikiran. Jika anggotanya tidak lengkap, maka hasil yang diperoleh menjadi minim.

Pembelajaran daring saat ini dijadikan solusi dalam masa pandemic Covid19, tetapi pembelajaran daring tidak mudah seperti yang dibayangkan (Dewi, 2020:59). Beberapa dampak yang dirasakan murid yaitu murid belum ada budaya belajar jarak jauh karena selama ini sistem belajar dilaksanakan adalah melalui tatap muka, murid terbiasa berada di sekolah untuk berinteraksi dengan teman- 
temannya, bermain dan bercanda gurau dengan teman-temannya serta bertatap muka dengan para gurunya, dengan adanya metode pembelajaran jarah jauh membuat para murid perlu waktu untuk beradaptasi dan mereka menghadapi perubahan baru yang secara tidak langsung akan mempengaruhi daya serap belajar mereka.

Hambatan-hambatan yang dihadapi dan cara mengatasi pelaksanaan model aksi insiden, baik siklus pertama maupun siklus kedua. Siswa terlambat mengumpulkan tugas karena mengikuti lomba debat.

Tabel 4. Hambatan-Hambatan yang Dihadapi

\begin{tabular}{clll}
\hline No. & \multicolumn{1}{c}{ Hambatan yang Dihadapi } & \multicolumn{1}{c}{ Solusi } \\
\hline 1. & Siswa kehabisan kuota. & Sekolah/pemerintah memberi kuota gratis. \\
\hline 2. & Jaringan macet. & Memberi waktu deadline agak lama. \\
\hline 3. & $\begin{array}{l}\text { Tiga orang siswa lomba debat } \\
\text { tingkat provinsi. }\end{array}$ & Guru merubah tenggat waktu. \\
\hline 4. & $\begin{array}{l}\text { Siswa mengunggah video banyak } \\
\text { terkendala. }\end{array}$ & $\begin{array}{l}\text { Guru membimbing lewat whatsapp dan } \\
\text { menyuruh simpan di geogle drive. }\end{array}$ \\
\hline
\end{tabular}

\section{Simpulan}

Penerapan model aksi insiden berbasis classroom mampu meningkatkan kemampuan menulis teks eksplanasi pada masa pandemi Covid-19. Hal ini ditunjukkan dengan sebelum menerapkan model aksi insiden siswa memperoleh hasil belajar dengan nilai rata-rata sebesar 73,44 dengan kategori baik dan meningkat sesudah diterapkannya model aksi insiden dengan nilai rata-rata sebesar 83,16 dengan kategori sangat baik. Kemudian, hasil siklus 1 ke 2 mengalami kenaikan 1,16 \%. Dari hasil angket diperoleh $63,75 \%$ siswa setuju model aksi insiden berbasis classroom diterapkan masa pandemi Covid-19, diperoleh dengan kategori baik. Model aksi insiden berbasis classroom memiliki kelebihan mampu meningkatkan kreativitas siswa ketika proses kegiatan menulis teks eksplanasi karena setiap individu dalam kelompok menyumbangkan idenya dalam bentuk tulisan eksplanasi.

Model aksi insiden menyampaikan pesan kepada siswa sesuai target KD sehingga dapat memotivasi siswa, bergairah dalam belajar, dan berpengaruh memberantas karakter malas mengumpulkan tugas. Model ini bagus diterapkan dalam pembelajaran jarak jauh. Siswa digembleng menulis teks eksplanasi 
dengan menyumbang ide lewat investigasi kelompok, pembelajarannya variatif (kelompok dan individu), dan siswa cepat mengumpulkan tugas karena menggunakan tenggat waktu. Model ini anggota kelompok harus lengkap, agar tugas kelompok tidak terhambat demi memperoleh poin tinggi. Otomatis temannya mengingatkan. Model ini meningkatkan motivasi, antusias siswa dalam belajar semakin tinggi, dan siswa terlatih berkerja sama serta meningkatkan rasa sosial yang tinggi. Keunggulan model aksi insiden berbasis classroom lainnya yaitu: 1) dapat digunakan pada semua mata pelajaran, 2) dapat meningkatkan motivasi, hasil, dan aktivitas belajar, 4) Model aksi insiden memperoleh pengalaman yang berbeda, tercipta kompetisi, dan belajar menjadi bergairah.

Guru diharapkan agar berdedikasi tinggi, profesional, kreatif, inovatif, sungguh-sungguh dalam mentrasfer ilmu kepada siswanya, sekaligus menjadi guru yang inspiratif untuk mencerdaskan generasi bangsa. Harapan ke depannya, penggunaan model aksi insiden ini ditindaklanjuti dan dikembangkan sebagai bahan refleksi bagi rekan guru yang lainnya. Model aksi insiden ini dapat menyelesaikan masalah belajar masa pandemi Covid-19 sehingga hasil belajar menulis teks eksplanasi tetap berjalan maksimal.

\section{Daftar Pustaka}

Arikunto, S. (2006). Prosedur Penelitian Suatu Pendekatan Praktik Edisi Revisi VI. Jakarta: Rineka Cipta.

Ayuni, D., Marini, T., Fauziddin, M., \& Pahrul, Y. (2020). Kesiapan Guru TK Menghadapi Pembelajaran Daring Masa Pandemi Covid-19. Jurnal Obsesi: Jurnal Pendidikan Anak Usia Dini, 5(1), 415. doi:10.31004/obsesi.v5i1.579

Dewi, W. A. F. (2020). Dampak COVID-19 terhadap Implementasi Pembelajaran Daring di Sekolah Dasar. Edukatif: Jurnal IImu Pendidikan, 2(1), 58-59. doi:10.31004/edukatif.v2i1.89

Dharmawan, K., Ramona, Y., Rupiasih, N., \& Nilakusumawati, D.P.E. (2015). Pemanfaatan Aplikasi Google Docs sebagai Media Pembinaan Karya Ilmiah Remaja. Prosiding Pertemuan dan Presentasi Karya IImiah: Inovasi Teknologi Informasi dan Komunikasi dalam Menunjang Technopreneurship, $\quad$ Bali, $23 \quad$ Oktober 2015. 
https://simdos.unud.ac.id/uploads/file_pengabdian_dir/ede0ce1282a56ebc 98b609eadabc5e9b.pdf

Gunawan, F.I. \& Sunarman, S.G. (2018). Pengembangan Kelas Virtual dengan Google Classroom dalam Keterampilan Pemecahan Masalah (Problem Solving) Topik Vektor pada Siswa SMK untuk Mendukung Pembelajaran. Prosiding Seminar Nasional Pendidikan Matematika Etnomatnesia, https://jurnal.ustjogja.ac.id/index.php/etnomatnesia/article/view/2334

Keputusan Kepala Badan Penelitian dan Pengembangan dan Perbukuan Nomor 018/H/KR/2020. Silabus PJJ Khusus Pandemi Covid- 19.

Kunandar. (2008). Langkah Mudah Penelitian Tindakan Kelas sebagai Pengembangan Profesi Guru. Jakarta: Raja Grafindo Persada.

Mahsun. (2014). Teks dalam Pembelajaran Bahasa Indonesia Kurikulum 2013. Jakarta: PT RajaGrafindo Persada.

Mulia, D.S. \& Suwarno, S. (2016). PTK (Penelitian Tindakan Kelas) dengan Pembelajaran Berbasis Kearifan Lokal dan Penulisan Artikel Ilmiah di SD Negeri Kalisube, Banyumas. Khazanah Pendidikan, IX(2), http://jurnalnasional.ump.ac.id/index.php/khazanah/article/view/1062

Mustofa, M. I., Chodzirin, M., Sayekti, L., \& Fauzan, R. (2019). Formulasi Model Perkuliahan Daring sebagai Upaya Menekan Disparitas Kualitas Perguruan Tinggi. Walisongo Journal of Information Technology, 1(2), 154. doi:10.21580/wjit.2019.1.2.4067

Nirfayanti \& Nurbaeti. Pengaruh Media Pembelajaran Google Classroom dalam Pembelajaran Analisis Real terhadap Motivasi Belajar Mahasiswa. Jurnal Penelitian Matematika dan Pendidikan Matematika, 2(1), https://ejournal.my.id/proximal/article/view/211

Sabran, E. S. (2019). Keefektifan Google Classroom sebagai Media pembelajaran. Prosiding Seminar Nasional Lembaga Penelitian Universitas Negeri Makasar "Diseminasi Hasil Penelitian melalui Optimalisasi Sinta dan Hak Kekayaan Intelektual”. ISBN : 978-602-555471-1.

Sadikin, A., \& Hamidah, A. (2020). Pembelajaran Daring di Tengah Wabah Covid19. BIODIK, 6(2), 109-110. doi:10.22437/bio.v6i2.9759

Sari, M.H., Susetyo, Noermanzah, Wardhana, D.E.C., Kusumaningsih, D. (2020). Understanding the Level of Students' Reading Comprehension Ability. Universal Journal of Educational Research, 8(5). https://doi.org/10.13189/ujer.2020.080521 
Surat Edaran Sekjen Kementerian P \& K No. 15 tahun 2020. Pedoman Penyelenggaraan Belajar dari Rumah dalam Masa Darurat Penyebaran Covid- 19.

Susilowati, D. (2018). Penelitian Tindakan Kelas (PTK) Solusi Alternatif Problematika Pembelajaran. Jurnal Ilmiah Edunomika, 2(1), 40-41, doi:10.29040/jie.v2i01.175

Tantri, N. R. (2018). Kehadiran Sosial dalam Pembelajaran Daring Berdasarkan Sudut Pandang Pembelajar Pendidikan Terbuka dan Jarak Jauh. Jurnal Pendidikan Terbuka dan Jarak Jauh, 19(1), 29. doi:10.33830/ptjj.v19i1.310.2018

Silampari Bisa: Jurnal Penelitian Pendidikan Bahasa Indonesia, Daerah, dan Asing Vol. 3, No. 2, 2020 